indirect, yet powerful indicator of the impact of MTX therapy on patients' quality of life.

Disclosure of Interests: Giulio Cavalli Consultant of: SOBI, Pfizer, Sanofi, Novartis, Paid instructor for: SOBI, Novartis, Speakers bureau: SOBI, Novartis, Martina Biggioggero: None declared, adriana cariddi: None declared, Giacomo De Luca Speakers bureau: SOBI, Novartis, Celgene, Pfizer, MSD, Elena Agape: None declared, nicola boffini: None declared, Elena Baldissera Speakers bureau: Novartis, Pfizer, Roche, Alpha Sigma, Sanofi, Lorenzo Dagna: None declared, Ennio Giulio Favalli Consultant of: Consultant and/or speaker for BMS, Eli-Lilly, MSD, UCB, Pfizer, Sanofi-Genzyme, Novartis, and Abbvie, Speakers bureau: Consultant and/or speaker for BMS, Eli-Lilly, MSD, UCB, Pfizer, Sanofi-Genzyme, Novartis, and Abbvie

DOI: 10.1136/annrheumdis-2020-eular.4242

\section{AB0337 TOFACITINIB MONOTHERAPY OR COMBINED WITH METHOTREXATE IN PATIENTS WITH RHEUMATOID ARTHRITIS SHOW SIMILAR RETENTION OVER FOUR YEARS. REPORT FROM RHUMADATA $®$}

D. Choquette ${ }^{1}$, L. Bessette ${ }^{2}$, L. Choquette Sauvageau', I. Ferdinand ${ }^{1}$, B. Haraoui ${ }^{1}$, F. Massicotte ${ }^{1}$, J. P. Pelletier ${ }^{1}$, J. P. Raynauld ${ }^{1}$, M. A. Rémillard ${ }^{1}$, D. Sauvageau ${ }^{1}$, É. Villeneuve ${ }^{1}$, L. Coupal ${ }^{1} .{ }^{1}$ Institut de Recherche en Rhumatologie de Montréal, Montréal, Canada; ${ }^{2}$ Centre de l'Ostéoporose et de Rhumatologie de Québec, Québec, Canada

Background: Since the introduction of biologic agents around the turn of the century, the scientific evidence shows that the majority of agents, independent of the therapeutic target, have a better outcome when used in combination with methotrexate (MTX). In 2014, tofacitinib (TOFA), an agent targeting Janus kinase 1 and 3 , has reached the Canadian market with data showing that the combination with MTX may not be necessary $[1,2]$.

Objectives: To evaluate the efficacy and retention rate of TOFA in real-world patients with rheumatoid arthritis (RA).

Methods: Two cohorts of patients prescribed TOFA was created. The first cohort was formed of patients who were receiving MTX concomitantly with TOFA (COMBO) and the other of patients using TOFA in monotherapy (MONO). MONO patients either never use MTX or were prescribed MTX post-TOFA initiation for at most $20 \%$ of the time they were on TOFA. COMBO patients received MTX at the time of TOFA initiation or were prescribed MTX post-TOFA initiation for at least $80 \%$ of the time. For all those patients, baseline demographic data definitions. Disease activity score and HAQ-DI were compared from the initiation of TOFA to the last visit. Time to medication discontinuation was extracted, and survival was estimated using Kaplan-Meier calculation for MONO and COMBO cohorts.

Results: Overall, 194 patients were selected. Most were women (83\%) on average younger than the men (men: $62.6 \pm 11.0$ years vs. women: 56.9 \pm 12.1 years, $p$-value=0.0130). The patient's assessments of global disease activity, pain and fatigue were respectively $5.0 \pm 2.7,5.2 \pm 2.9,5.1 \pm$ 3.1 in the COMBO group and $6.2 \pm 2.5,6.5 \pm 2.6,6.3 \pm 2.8$ in the MONO group all differences being significant across groups. HAQ-DI at treatment initiation was $1.3 \pm 0.7$ and $1.5 \pm 0.7$ in the COMBO and MONO groups, respectively, $p$-value $=0.0858$. Similarly, the SDAI score at treatment initiation was $23.9 \pm 9.4$ and $25.2 \pm 11.5, p$-value $=0.5546$. Average changes in SDAI were $-13.4 \pm 15.5$ (COMBO) and $-8.9 \pm 13.5$ (MONO), p-value $=0.1515$, and changes in $\mathrm{HAQ}-0.21 \pm 0.63$ and $-0.26 \pm 0.74$, p-value 0.6112. At treatment initiation, DAS28(4)ESR were $4.4 \pm 1.4$ (COMBO) and $4.6 \pm 1.3$ (MONO), p-value 0.5815 , with respective average changes of $-1.06 \pm 2.07$ and -0.70 $\pm 1.96, p$-value $=0.2852$. The Kaplan-Meier analysis demonstrated that the COMBO and MONO retention curves were not statistically different (log-rank $\mathrm{p}$-value $=0.9318)$.

Conclusion: Sustainability of TOFA in MONO or COMBO are not statistically different as are the changes in DAS28(4)ESR and SDAI. Despite this result, some patients may still benefit from combination with MTX.

References:

[1] Product Monograph - XELJANZ @ (tofacitinib) tablets for oral administration Initial U.S. Approval: 2012.

[2] Reed GW, Gerber RA, Shan Y, et al. Real-World Comparative Effectiveness of Tofacitinib and Tumor Necrosis Factor Inhibitors as Monotherapy and Combination Therapy for Treatment of Rheumatoid Arthritis [published online ahead of print, 2019 Nov 9]. Rheumatol Ther. 2019;6(4):573-586. doi:10.1007/ s40744-019-00177-4.

Disclosure of Interests: Denis Choquette Grant/research support from: Rhumadata is supported by grants from Pfizer, Amgen, Abbvie, Gylead, BMS, Novartis, Sandoz, eli Lilly,, Consultant of: Pfizer, Amgen, Abbvie, Gylead, BMS, Novartis, Sandoz, eli Lilly,, Speakers bureau: Pfizer, Amgen, Abbvie, Gylead, BMS, Novartis, Sandoz, eli Lilly,, Louis Bessette Grant/ research support from: AbbVie, Amgen, Bristol-Myers Squibb, Celgene, Eli Lilly, Janssen, Merck, Novartis, Pfizer, Roche, Sanofi, UCB Pharma, Consultant of: AbbVie, Amgen, Bristol-Myers Squibb, Celgene, Eli Lilly, Janssen, Merck, Novartis, Pfizer, Roche, Sanofi, UCB Pharma, Speakers bureau: AbbVie, Amgen, Bristol-Myers Squibb, Celgene, Eli Lilly, Janssen Merck, Novartis, Pfizer, Sanofi, Loïc Choquette Sauvageau: None declared, Isabelle Ferdinand Consultant of: Pfizer, Abbvie, Amgen, Novartis, Speak ers bureau: Pfizer, Amgen, Boulos Haraoui Grant/research support from: Abbvie, Amgen, Pfizer, UCB, Grant/research support from: AbbVie, Amgen BMS, Janssen, Pfizer, Roche, and UCB, Consultant of: Abbvie, Amgen, Lilly, Pfizer, Sandoz, UCB, Consultant of: AbbVie, Amgen, BMS, Celgene, Eli Lilly, Janssen, Merck, Pfizer, Roche, and UCB, Speakers bureau: Pfizer, Speakers bureau: Amgen, BMS, Janssen, Pfizer, and UCB, Frédéric Massicotte Consultant of: Abbvie, Janssen, Lilly, Pfizer, Speakers bureau: Janssen, Jean-Pierre Pelletier Shareholder of: ArthroLab Inc., Grant/research support from: TRB Chemedica, Speakers bureau: TRB Chemedica and Mylan, Jean-Pierre Raynauld Consultant of: ArthroLab Inc., Marie-Anaïs Rémillard Consultant of: Abbvie, Amgen, Eli Lilly, Novartis, Pfizer, Sandoz, Paid instructor for: Abbvie, Amgen, Eli Lilly, Novartis, Pfizer, Sandoz, Speakers bureau: Abbvie, Amgen, Eli Lilly, Novartis, Pfizer, Sandoz, Diane Sauvageau: None declared, Édith Villeneuve Consultant of: Abbvie, Amgen, BMS, Celgene, Pfizer, Roche, Sanofi-Genzyme,

UCB, Paid instructor for: Abbvie, Speakers bureau: AbbVie, BMS, Pfizer, Roche Louis Coupal: None declared DOI: 10.1136/annrheumdis-2020-eular.2479

\section{AB0338 $\quad$ EVALUATION OF THE ASSOCIATION OF ALLELES OF INTOLERANCE RISK TO METOTREXATE IN RHEUMATOID ARTHRITIS PATIENTS UNDER TREATMENT WITH BIOLOGIC THERAPIES}

A. Escudero Contreras ${ }^{1}$, R. Ortega Castro ${ }^{1}$, J. Calvo Gutierrez ${ }^{1}$, N. MenaVázquez $^{2}$, R. Cáliz Cáliz ${ }^{3}$, E. Collantes Estevez ${ }^{1}$, A. Fernandez-Nebro ${ }^{4}$, M. D. C. Abalos-Aguilera ${ }^{1}$, C. Lopez-Pedrera ${ }^{1}$, M. T. Ruiz Jimenez ${ }^{5}$, F. U. Pilar ${ }^{1}{ }^{1}{ }^{1}$ Hospital Universitario Reina Sofía, Córdobal Maimonides Biomedical Research Institute of Cordoba (IMIBIC)/University of Cordoba, Rheumatology, Cordoba, Spain; ${ }^{2}$ Hospital Carlos Haya, Malaga, Malaga, Spain; ${ }^{3}$ Complejo Hospitalario Universitario, Granada, Spain; ${ }^{4} \mathrm{Hospital}$ Carlos Haya, Malaga, Spain; ${ }^{5}$ Roche Farma, Madrid, Madrid, Spain

Background: Metotrexate (MTX) is the first-line treatment for rheumatoid arthritis (RA) both in monotherapy and in combination with biologic disease-modifying antirheumatic drugs (bDMARDs), it usually well tolerated but AEs may appear that causing toxicity that requires suspension of the treatment

Objectives: Determine the prevalence of certain polymorphisms among patients that receive bDMARD in monotherapy or in combination with MTX to confirm its relevance as biomarkers of intolerance. Evaluate the influence of certain polymorphisms in the effectiveness of monotherapy or combined treatment in patients, through "Disease Activity Score 28" (DAS28), SDAI Simple disease activity index (SDAI), Clinical disease activity index (CDAI) and each one of its components

Methods: Retrospective observational multicentric study (University Hospital Complex, Granada, Carlos de Haya Hospital, Malaga and University Hospital Reina Sofia, Cordoba), of cases-control of 227 patients with RA (criteria ACR/ EULAR), of which 120 received MTX and bDMARD combined therapy (cases) and other with only bDMARD (controls). All of them had been or were currently treated with MTX, remained with stable doses of bDMARD, and had a DNA sample stored before the inclusion in the study

DNA was isolated from total peripheral blood and by fluorescent probe HybProbe and/ or Taqman, 10 polymorphisms of 10 protein coding genes were determined involved in the metabolism and toxicity of MTX according to current evidence

Besides the type of polymorphism, data on the activity of the disease were analysed (DAS28VSG, DAS28PCR, SDAI, CDAI, at the start of the MTX income, of the $\mathrm{BT}$, and in the inclusion visit

A descriptive and comparative study was carried out on all that and afterwards an assessment was made through a multiple logistic regression analysis (MLR) on the risk of intolerance to MTX

Results: An analysis was carried out on 227 patients (120 cases and 107 controls) with an average age of $60(12,1)$ being women $78,4 \%$, with a time of evolution since diagnosis of $14,84(7,78)$ years

$48,9 \%$ registered adverse events (AE) MTX related, mainly gastrointestinal, hepatobiliary and skin-subcutaneous tissue. The percentage of $A E$ appearance was superior in the monotherapy group than in the group with combined therapy 
The most prevalent polymorphism (84,6\% (IC95\%: 84,09\%-85,11\%) and in cases (86,0\% (IC95\%: 79,43\%-92,57\%) was homozygous CC (ITPase-c94a); in controls homozygous GG (GGH-T401C) (87,5\% (IC95\%:81,58\%-93,42\%)

There were no significant differences in the parameters of activity between groups, in both, patients were best basally controlled than at the start of the MTX income and/or bDMARD

Being homozygous-AA for the DHFR gene was significantly associated $(p<0.05)$ with the appearance of AE (none of the 4 homozygous AA patients for that gene had $\mathrm{AE}$ )

In MLR, homozygous GG (ref. heterozygous AG) in polymorphism GGH-T401C, being homozygous CC (ref. heterozygous TC) in polymorphism ABCC2-C24T and PCR $(\mathrm{mg} / \mathrm{dL})$ at the start of bDMARD resulted independent predictive factors of MTX intolerance

Conclusion: Polymorphisms T401C for the GGH gene and C24T for the ABCC2 gene and PCR at the start of the bDMARD resulted independent predictive factors of MTX intolerance

. Polymorphism homozygous AA for DHFR gene was related to significant protection against appearance of $A E$

Disclosure of Interests: Alejandro Escudero Contreras: None declared, Rafaela Ortega Castro: None declared, Jerusalem Calvo Gutierrez: None declared, Natalia Mena-Vázquez: None declared, Rafael Cáliz Cáliz: None declared, Eduardo Collantes Estevez Grant/research support from: ROCHE and Pfizer, Speakers bureau: ROCHE, Lilly, Bristol and Celgene, Antonio Fernandez-Nebro: None declared, Maria del Carmen Abalos-Aguilera: None declared, Chary Lopez-Pedrera Grant/research support from: ROCHE and Pfizer., $\mathrm{M}^{\mathrm{a}}$ Teresa Ruiz Jimenez Employee of: Roche Farma, SPAIN, Font Ugalde Pilar: None declared

DOI: 10.1136/annrheumdis-2020-eular.3258

\section{AB0339 2 THE IMPORTANCE OF THERAPEUTIC COMPLIANCE ADHERENCE TO METHOTREXATE AND ITS ROLE IN IMMUNOGENICITY}

P. García ${ }^{1}$, M. González Fernández ${ }^{1}$, M. N. Rivas ${ }^{1}$, J. Duruelo ${ }^{1}$, E. Garmendia ${ }^{1}$, J. Arostegui Lavilla ${ }^{1}$, F. Perez-Ruiz ${ }^{1}$, A. Alonso ${ }^{1}$, C. Modesto ${ }^{1}$, B. A. Blanco Cáceres ${ }^{2} .{ }^{1}$ Hospital Universitario Cruces, Barakaldo, Spain; ${ }^{2}$ Hospital Ramón y Cajal, Madrid, Spain

Background: Immunogenicity against adalimumab leads to loss of response and secondary failure to biologic therapy; however, concomitant use of methotrexate (MTX) seems to reduce the development of anti-drug antibodies (ADAbs) in a dose-dependent manner. Suboptimal adherence to MTX may favour ADAbs appearance.

Objectives: To evaluate the relationship between MTX adherence and ADAbs development.

Methods: Observational study among adult patients with chronic inflammatory arthropathy, followed in a tertiary care centre, who were in treatment with MTX and adalimumab. ADAbs formation in relation to MTX adherence was assessed. Results: 33 patients were included, with a MTX adherence overall mean of 82.13 (12.45\%-100\%, median adherence $92.19 \%)$. Only $9.09 \%(n=3)$ of the patients developed ADAbs, being its MTX adherence mean of $60.95 \%(46.47 \%-70 \%$, median adherence $66.39 \%$ ); ADAbs negative group showed an average MTX adherence of $84.23 \%$ (12.45\%-100\%, median adherence $94.29 \%)$. A statistically significant result $(p<0.05)$ between groups was found.

\begin{tabular}{lccc}
\hline & $\mathbf{n}$ & $\begin{array}{c}\text { Adherence } \\
\text { mean }\end{array}$ & \\
\hline ADAbs $(+)$ & $3(9.09 \%)$ & $60.95 \%$ & $\mathrm{p}<0.05$ \\
ADAbs $(-)$ & $30(90.91 \%)$ & $84.23 \%$ & \\
Total & $33(100 \%)$ & $82.13 \%$ & \\
\hline
\end{tabular}

No statistically significant differences $(\mathrm{p}>0.05)$ involving MTX adherence and its dose were found.

Conclusion: While the sample is small, this study suggests that ADAbs development may be influenced by MTX adherence, thereby promoting adequate MTX adherence should be a priority in the daily practice of every rheumatologist.

References:

[1] World Health Organization. Adherence to long term therapies: evidence for action. 2003
[2] Krieckaert CL, Nurmohamed MT, Wolbink GJ. Methotrexate reduces immunogenicity in adalimumab treated rheumatoid arthritis patients in a dose dependent manner. Annals of the Rheumatic Diseases. 2012;71:1914-1915

[3] Zhang J, Xie F, Delzell E, et al. Impact of biologic agents with and withou concomitant methotrexate and at reduced doses in older rheumatoid arthritis patients. Arthritis Care Res (Hoboken). 2015;67(5):624-632. doi:10.1002/ acr.22510

[4] Jani M, Barton A, Warren RB, Griffiths CE, Chinoy H. The role of DMARDs in reducing the immunogenicity of TNF inhibitors in chronic inflammatory diseases. Rheumatology (Oxford). 2014;53(2):213-222. doi:10.1093/ rheumatology/ket260.

Disclosure of Interests: Paula García: None declared, Marta González Fernández: None declared, Mayra Nathali Rivas: None declared, Javier Duruelo: None declared, Elena Garmendia: None declared, Javier Arostegui Lavilla: None declared, Fernando Perez-Ruiz Consultant of: Amgen

Lilly, Speakers bureau: Amgen, Alberto Alonso: None declared, Consuelo Modesto: None declared, Boris Anthony Blanco Cáceres: None declared DOI: 10.1136/annrheumdis-2020-eular.4803

\section{AB0340 EFFECT OF BARICITINIB ON RANKL SERUM CONCENTRATION IN RHEUMATOID ARTHRITIS PATIENTS}

C. Garufi ${ }^{1}$, F. R. Spinelli ${ }^{1}$, F. Ceccarelli ${ }^{1}$, S. Mancuso ${ }^{1}$, C. Barbati ${ }^{1}$, T. Colasanti ${ }^{1}$, C. Alessandri ${ }^{1}$, F. Conti ${ }^{1} .{ }^{1}$ Sapienza University of Rome, Rome, Italy

Background: RANKL (receptor activator of nuclear factor $\mathrm{KB}$ ligand) and osteoprotegerin, the main regulators of bone metabolism, are involved in osteoblasts/ osteoclasts balance in inflammatory disease, such as Rheumatoid Arthritis (RA). Janus kinase (JAK) inhibitors (baricitinib and tofacitinib) can reduce the progression of structural damage in patients with moderate to severe RA. Previous studies suggest a link between JAK inhibition, production of RANKL and osteoclastogenesis ${ }^{1,2}$

Objectives: to investigate the effect of baricitinib on RANKL serum concentration in unselected RA patients.

Methods: Patients affected by RA according to 2010 ACR criteria, starting treatment with baricitinib as clinically indicated, were consecutively enrolled. Demographic, clinical and laboratory data were collected at baseline (TO) and after three months of therapy (T3). RANKL serum concentration was analyzed by ELISA at the same timepoints. All patients underwent ultrasound (US) examination at TO and T3. According with OMERACT definitions, the presence of synovial effusion, hypertrophy and power Doppler were assessed and scored on a semi-quantitative scale $(0=a b s e n t, 1=$ mild $2=$ moderate, $3=$ severe), obtaining a total US score $(0-198)$, representing the joint inflammatory status (15); erosions were registered. Data were expressed as median (interquartile range); Mann-Whitney and Spearman tests were performed for comparisons and $p$ values $<0.05$ were considered statistically significant.

Results: We prospectively followed up $33 \mathrm{RA}$ patients starting treatmen with baricitinib [M/F 8/25; age 58(9) years; disease duration 165(150) months; $22 / 33$ (67\%) ACPA-anti-citrullinated protein antibody positive $24 / 33$ patients (73\%) RF-rheumatoid factor positive]. After three months of therapy we observed a significant reduction of DAS28 ${ }_{\mathrm{CRP}}, \mathrm{CDAI}$ and SDAI compared to baseline $(p<0.0001)$. The US inflammatory score showed a significant improvement at T3 $(p<0.0001)$. The serum concentration of RANKL showed a significant decrease after three months of therapy from 44 (25.9) to 27.5 (35.3) $\mathrm{pg} / \mathrm{ml}, p=0.0256$ (Figure 1 ). While in $67 \%$ of patients RANKL decreased after treatment, in $33 \%$ of patients no decrease or an increase of RANKL was detected. Those patients showing an increase of RANKL had similar DAS28 ${ }_{\mathrm{CRP}}$, CDAI, SDAI, but had significantly less swollen joints, compared to those in which RANKL decreased $(p=0.0364)$. At baseline, the concentration of RANKL significantly correlated with the swollen joint count $(p=0.0117)$ and ESR $(p=0.0482)$, but not with DAS28 ${ }_{\mathrm{CRP}}$, CDAI, SDAI nor with the US inflammatory score. Nevertheless, the reduction of RANKL was not significantly associated with the achievement of low disease/remission after three months of treatment, with ACPA/RF positivity or the presence of erosions detected by US.

Conclusion: This is the first study demonstrating that baricitinib reduces in vivo the serum levels of RANKL, regardless the correlation with disease activity indices. The discrepancy between the levels of RANKL and the clinical response is in line with previous data in the literature, demonstrating that under treatment with anti-TNF and anti-IL1, the decrease of RANKL did not 